\title{
Nutrition transition in Poland: a review of the epidemiological data on dietary intake and the prevalence of overweight and obesity pre- and post-communism
}

\author{
A. Szynszecka and D. Bhakta \\ London Metropolitan University, London N7 8DB, UK
}

In 1989, communist rule was overthrown in Poland, one of the largest economies in Europe with a population of over 38 million ${ }^{(1)}$, and the country successfully transformed itself into a booming capitalistic market economy. This led to rapid changes in lifestyle behaviour including increase in food accessibility and availability, the use of cars, the duration of television viewing and sedentary activity, changes which are typical of countries undergoing rapid economic and nutrition transition ${ }^{(2)}$.

A literature review was conducted to investigate if changes in the Polish economy were reflected in dietary intake and the prevalence of overweight and obesity pre- and post communism. The majority of the literature search was conducted in Poland using the Library of the Medical University of Gdansk as the primary source, and many of the papers had to be translated from Polish to English. Studies were included if appropriate dietary assessment tools of 3- to 7-d weighed diary and multiple $24 \mathrm{~h}$ recalls were used, and if anthropometric measurements were conducted using standardised procedures. A total of 25 studies were selected for review, which included six large cohort studies and 13 cross-sectional studies.

A review of four ${ }^{(3-6)}$ relatively large dietary intake studies showed that the average proportion of energy from fat intake increased from $36 \%$ in 1989 to $39 \%$ in 2003, and subsequently the proportion of energy from carbohydrate intake decreased from $50 \%$ to $47 \%$ during the same period. The proportion of energy intake from protein remained largely unchanged. The epidemiological evidence also revealed a gradual, but steady increase in adult mean BMI from $21.4 \mathrm{~kg} / \mathrm{m}^{2}$ in $1971^{(7)}$ to $23.4 \mathrm{~kg} / \mathrm{m}^{2}{ }^{(8)}$ in 2002 . A similar pattern was observed in studies, which examined changes in BMI in children ${ }^{(8-10)}$, rising from $15.6 \mathrm{~kg} / \mathrm{m}^{2}$ in 1971 to $17.4 \mathrm{~kg} / \mathrm{m}^{2}$ in 2002 . This pattern was further emphasised in the increased prevalence of overweight and obesity in adults from $5.6 \%$ and $1 \%$ in $1971^{(9)}$ to $11.9 \%$ and $2.5 \%$ in $2001^{(7)}$, respectively. A more rapid increase was observed in the prevalence of overweight and obesity in children rising from $5.5 \%$ and $0.6 \%$ in $1971^{(9)}$ to $16.9 \%$ and $6 \%$, respectively, in $2007^{(10)}$. It is evident that there is a growing body of evidence to show that Poland is in rapid nutrition transition and timely interventions to decrease risk from chronic disease may be necessary.

1. Central Statistics Office (2008) Poland.

2. Popkin BM (2006) Food Policy 31, 554-569.

3. Charzewska J et al. (1992) Zywienie cztowieka i metabolism 19, 17-25.

4. Chwojnowska Z et al. (1992) Żywienie Cztowowieka i Matabolism 19, 165-175.

5. Augustyniak U \& Brzozowska A (2002) Roczniki Polskiego Zakladu Higieny 53, 399-406.

6. Ostrowska A et al. (2003) Zywienie Czlowieka i Metabolism 30, 362-366.

7. Koziel S, Szklarska A, Bielicki T et al. (2006) Intl J Obesity 30, 1382-1388.

8. Kułaga Z, Krzyżaniak A, Palczewka et al. (2007) Standardy Medyczne 4, 267-271.

9. Chrzanowska M, Koziel S \& Ulijaszek (2007) Econ Hum Biol 5, 370-378.

10. Abramowicz P, Białkoz-Kalinowska I, Konstantynowicz J et al. (2007) Pediatria Polska 83, 408-413. 